\title{
KEWENANGAN DIREKTORAT RESERSE NARKOBA POLDA JATENG DALAM PENANGANAN TINDAK PIDANA NARKOBA
}

\author{
Muhammad Muanam, Kukuh Sudarmanto, Zaenal Arifin, \\ Amri Panahatan Sihotang
}

Magister Hukum Universitas Semarang, Semarang

muh.anam41@gmail.com

\begin{abstract}
Abstrak
Tujuan penelitian ini adalah untuk mengkaji kewenangan Direktorat Reserse Narkoba Polda Jateng dalam penanganan tindak pidana Narkoba dan untuk memahami dan menganalisa kendala dan solusi kewenangan Direktorat Reserse Narkoba Polda Jateng dalam penanganan tindak pidana Narkoba. Metode dalam penelitian ini menggunakan metode penelitian deskriptif kualitatif. Hasil penelitian ini adalah : Kewenangan Direktorat Reserse Narkoba Polda Jateng dalam penanganan tindak pidana Narkoba secara garis besarmya dapat dibagi menjadi 2 yaitu lewat jalur "penal" (hukum pidana) dan jalur non penal. Dalam penerapan pidana terhadap tindak pidana narkotika dikenakan Undang-Undang Nomor 35 tahun 2009 tentang narkotika, baik itu bagi masyarakat umum maupun anggota Kepolisian. Jalur non penal yaitu dengan "memberikan penyuluhan-penyuluhan tentang bahayanya narkotika kepada masyarakat maupun anggota Polri serta ancaman pidana bila mereka melakukan tindak pidana narkotika”. Dalam menanggulangi kejahatan Narkoba di wilayah Jawa Tengah dan sekitarnya telah dilakukan upaya penal berupa tindakan represif. Penindakan hukum yang tegas bagi para pelanggar penyalahguna narkotika. Penindakan hukum secara tegas juga tidak pandang bulu baik itu kepada masyarakat maupun kepada oknum anggota Polri. Upaya kedua adalah memalui jalur non penal salah satunya melalui upaya pre-emtif (penyuluhan). Tindakan penyuluhan ini merupakan upaya pencegahan dengan mengenalkan bahaya dan ancaman narkaba kepada para generasi muda. Penyuluhan dilaksanakan di setiap sekolah menengah dan perguruan tinggi baik negeri maupun swasta.
\end{abstract}

Kata kunci : Direktorat Reserse Narkoba; Kewenangan; Tindak Pidana Narkoba

\section{AUTHORITY OF THE DIRECTORATE OF DRUG RESERSE OF JATENG POLDA IN HANDLING CRIMINAL ACTIONS OF DRUGS}

\begin{abstract}
The purpose of this study is to examine the authority of the Central Java Regional Police's Drug Reserse Directorate in handling drug crimes and to understand and analyze the constraints and solutions of the Central Java Regional Police's Narcotics Reserse Directorate in handling drug crimes. The method in this study uses a qualitative descriptive research method with a normative juridical approach. The results of this study are: The authority of the Central Java Regional Police's Drug Reserse Directorate in handling drug crimes can be broadly divided into 2, namely through the "penal" (criminal law) and non penal. In the application of crimes against narcotics crimes, Law Number 35 of 2009 concerning narcotics is imposed, both for the general public and for members of the Police. The non-penal route is by providing counseling on the dangers of narcotics to the public and members of the Police as well as the threat of punishment if they commit a narcotics crime. In tackling drug crimes in Central Java and its surroundings, efforts have been made to penalize them in the form of repressive measures. Strict legal action for drug abusers. Strict legal action is also indiscriminate, both to the community and to unscrupulous members of the Police. The second effort is through the non penal route, one of which is through pre-emptive (counseling) efforts. This counseling action is a prevention effort by introducing the dangers and threats of drugs to the younger generation. Counseling is carried out in every high school and university, both public and private.
\end{abstract}

Keywords: Directorate of Drug Research; Authority; Narcotics Crime 


\section{A. PENDAHULUAN}

Narkotika adalah "zat atau obat yang berasal dari tanaman atau bukan tanaman, baik sintetis maupun semisintetis, yang dapat menyebabkan penurunan atau perubahan kesadaran, hilangnya rasa, mengurangi sampai menghilangkan rasa nyeri, dan dapat menimbulkan ketergantungan, yang dibedakan ke dalam golongan-golongan (Undang-Undang No 35 Tahun 2009 tentang Narkotika)". Narkotika atau "drug" yaitu "sejenis zat yang apabila dipergunakan akan membawa efek dan pengaruhpengaruh tertentu pada tubuh si pemakai, yaitu : mempengaruhi kesadaran, memberikan dorongan yang dapat berpengaruh terhadap perilaku manusia dan pengaruh berupa penenang, perangsang (bukan rangsangan sex) dan menimbulkan halusinasi (pemakainya tidak mampu membedakan antara khayalan dan kenyataan, kehilangan kesadaran akan waktu dan tempat)". ${ }^{2}$

Peredaran narkotika di Indonesia tampaknya semakin marak. Dengan munculnya narkotika jenis baru yang belum diatur dalam Peraturan Menteri Kesehatan seperti kratom mengandung mitragynine dan speciogynine, berjenis tanaman, serbuk tanaman, berefek seperti opiat dan cocain, ketamin, berefek halusinasi, euphoria, psychotomimetic dan lain-lain. Masalah penyalahgunaan narkotika ini merupakkan masalah bersama yang tidak hanya perlu diperhatikan oleh Indonesia saja tetapi juga oleh dunia internasional, mengingat ancaman dan dampak akan bahaya Narkoba sangatlah besar. $^{3}$ Salah satu bentuk perhatian dunia internasional terhadap penyalahgunaan narkotika adalah dengan adanya penyelenggaraan konvensi internasional dan mendukung perang terhadap pemberantasan peredaran Narkoba. ${ }^{4}$

Kejahatan narkotika saat sangatlah berbahaya yang tidak hanya merusak secara fisik tetapi juga berbahaya bagi pskis dan mental seseorang yang terkena Narkoba. Narkoba juga dapat mengancam kedaulatan suatu negara karena secar tidak langsung Narkoba juga merusak generasi penerus yang selama ini selalu menjadi sasaran dalam peredaran Narkoba. ${ }^{5}$ Saat ini tren perkembangan penyalahguna Narkoba dari tahun ke tahun mengalami peningkatan baik secara kuantitas maupun kualitas. Hasil analisis Polri atas tingginya angka kejahatan tersebut salah satunya disebabkan oleh krisis ekonomi, dan rebdahnya pemahaman agama, hal inilah yang menjadikan pengedar Narkoba terus menjalankan aksinya. ${ }^{6}$

Undang-Undang Nomor 2 Tahun 2002 Tentang Kepolisian Negara Indonesia sendiri dibentuk dengan maksud agar Polri dapat bekerja secara profesional, mandiri,

\footnotetext{
${ }^{1}$ Undang-Undang No. 35 Tahun 2009 Tentang Narkotika, 2009, hlm 1.

${ }^{2}$ Moh. Taufik Makaro, Suhasril dan Moh. Zakky, "Tindak Pidana Narkotika”, Ghalia Indonesia, 2003 :16.

${ }^{3}$ Kusno Adi, "Kebijakan Kriminal Dalam Penanggulangan Tindak Pidana Narkotika Oleh Anak", UMM Press, Malang, 2009: 30.

${ }^{4}$ Kholilur Rahman, "Problem Pengaturan Upaya Paksa Penangkapan Terhadap Pelaku Tindak Pidana Narkotika”, Jurnal Hukum Ius Quia Iustum 27 (3), 2020 hal 487-500.doi : 10.20885/iustum.vol27.iss3.art3

${ }^{5}$ Wenda Hartanto, "Penegakan Hukum Terhadap Kejahatan Narkotika dan Obat-Obat Terlarang Dalam Era Perdagangan Bebas Internasionla Yang Berdampak Pada Keamanan dan Kedaulatan Negara”, Jurnal Legislasi 14 (1), 2017.

6 O.C Kaligis \& Associates, "Narkoba dan Peradilannya Di Indonesia”, Cetakan ke-2 (PT. Alumni Bandung, 2007): 7.
} 
berkualitas dan memiliki integritas. Dalam melaksanakan tugas dan tanggung jawabnya Polri tetap menjunjung tinggi hak asasi manusia, terciptanya rasa keadilan bagi masyarakat. Sehingga ketertiban, kedamaian dan keamanan di masyarakat akan tercipta dengan sendirinya ${ }^{7}$

Penelitian tentang penanganan tindak pidana Narkoba oleh Polri pernah diangkat dalam penelitian sebelumnya oleh Firdaus (2020) yang berjudul "Efektivitas Fungsi Institusi Kepolisian Dalam Pemberantasan Narkotika Di Kota Makassar." Penelitian ini fokus mengkaji bagaimana efektivitasnya Polri dalam pemberantasan Narkoba di Kota Makassar, serta menganalisis faktor-faktor yang mempengaruhi tingkat efektivitas pemberantasan Narkoba yang ada di Kota Makassar. Hasil penelitian ini menunjukkan bahwa Polri dalam melaksanan tugas pemberantasan Narkoba belum berjalan efektif. Tidak efektifnya Polri dalam melakukan pemberantasan Narkoba karena rendahnya faktor ketaatan hukum dan kurangnya sumber daya manusia, sarana dan prasarana serta minimnya biaya operasional. ${ }^{9}$

Sedangkan penelitian Wahono (2019) yang berjudul "Peranan Polri Dalam Pencegahan Dan Pemberantasan Penyalahgunaan Peredaran Gelap Narkoba Di Wilayah Hukum Polres Boyolali", penelitian tersebut fokus mengkaji tentang langkah Polres Boyolali dalam melakukan pencegahan dan pemberantasan Narkoba. Penelitian ini juga mengkaji kendala yang timbul dalam pencegahan dan pemberantasan Narkoba di wilayah hukum Polres Boyolali. ${ }^{7}$

Sedangkan penelitian oleh Goenawi (2019) dengan judul "Batas Kewenangan Antara Penyidik Polri Dalam Penegakan Tindak Pidana Narkoba", penelitian ini lebih fokus mengkaji tentang peran BNN dalam melakukan penyidikan tindak pidana Narkoba dan bagaimana batasan kewenangan yang dimiliki penyidik dari PPNS BNN dan penyidik Polri terkait dengan penanganan tindak pidana Narkoba. Adanya perbedaan tugas antara penyidik Polri dan penyidik dari PPNS BNN akan rentan menimbulkan permasalahan di lapangan dalam melaksanakan tugas pencegahan dan pemberantasan Narkoba. ${ }^{10}$

Penelitian ini melengkapi penelitian sebelumnya yang banyak membahas tentang kewenangan Polri dalam melakukan penindakan tindak pidana Narkoba. Penelitian ini lebih fokus tentang kewenangan penanganan Polda Jateng dalam menangani tindak pidana Narkoba. Penelitian Firdaus ini lebih fokus meneliti tentang keefektifan Polri dalam melakukan pemberantasan tindak pidana Narkoba di Kota Makassar. Sedangkan penelitian yang dilakukan oleh Wahono yang hanya meneliti bagaimana pencegahan dan pemberantasan Narkoba dalam ruang lingkup wilayah

${ }^{7}$ Kunarto, “Polisi Harapan dan Kenyataan”, Klaten : Sahabat, 1997: 24.

9 Hendar Firdaus, La Ode Husen,Abdul Agis, "Efektivitas Fungsi Institusi Kepolisian Dalam Pemberantasan Narkotika Di Kota Makassar", Jurnal of Lex Generalis 1 (6), 2020, 774788.doi: https://doi.org/10.52103/jlg.v1i6.215

7 Tri Wahono, Burham Pranawa, Joko Mardiyanto, "Peranan Polri Dalam Pencegahan Dan Pemberantasan Penyalahgunaan Peredaran Gelap Narkoba Di Wilayah Hukum Polres Boyolali(Studi Kasus Di Polres Boyolali)", Jurnal Bedah Hukum 3 (2), 2019, 120-129.

${ }^{10}$ Ferry Kurniawan Goenawi, "Batas Kewenangan Antara Penyidik Polri Dalam Penegakan Tindak Pidana Narkoba”, Badamai Law Journal 4 (2), 2019. 
hukum Polres Boyolali. Sedangkan Goenawi lebih mengkaji tentang batasan kewenangan yang dimilik oleh penyidik BNN dan penyidik Polri dalam menangani tindak pidana Narkoba. Tujuan penelitian ini untuk menganalisa kewenangan Direktorat Reserse Narkoba Polda Jateng dalam penanganan tindak pidana Narkoba, dan kendala dan solusi yang dihadapi Direktorat Reserse Narkoba Polda Jateng dalam penanganan tindak pidana Narkoba.

\section{B. PERMASALAHAN}

Berdasarkan latar belakang tersebut, maka perumusan masalah dalam artikel ini adalah:

1. Bagaimana kewenangan Direktorat Reserse Narkoba Polda Jateng dalam penanganan tindak pidana Narkoba?

2. Bagaimana kendala dan solusi kewenangan Direktorat Reserse Narkoba Polda Jateng dalam penanganan tindak pidana Narkoba?

\section{METODE PENELITIAN}

Metode penelitian yang dipakai yaitu yuridis normatif. Menurut Soerjono Soekanto pendekatan yuridis normatif yaitu "penelitian hukum yang dilakukan dengan cara meneliti bahan pustaka atau data sekunder sebagai bahan dasar untuk diteliti dengan cara mengadakan penelusuran terhadap peraturan-peraturan dan literaturliteratur yang berkaitan dengan permasalahan yang diteliti."11 Sifat penelitian ini disesuaikan dengan masalah yang dipergunakan penelitian yang bersifat deskriptif analitis, yaitu "menggambarkan yang jelas, rinci dan sistematis tentang objek yang diteliti". Analitis artinya "data yang diperoleh akan dianalisis untuk pemecahan terhadap permasalahan sesuai dengan ketentuan hukum yang berlaku." Hal utama yang ingin didiskripsikan adalah kewenangan Direktorat Reserse Narkoba Polda Jateng dalam penanganan tindak pidana Narkoba.

\section{HASIL DAN PEMBAHASAN}

\section{Kewenangan Direktorat Reserse Narkoba Polda Jateng Dalam Penanganan Tindak Pidana Narkoba}

Penegakan hukum yang tegas terhadap penyalahgunaan Narkoba telah banyak dilakukan oleh aparat penegak hukum. Telah banyak kasus tindak pidana Narkoba yang telah diputus oleh pengadilan dan berakhir pada sanksi pidana penjara. Langkah penegakkan hukum yang tegas terhada penyalahguna Narkoba akan memberintak efek jera bagi para pelaku tindak pidana. Penegakan hukum Narkoba itu sendiri telah diangani 2 institusi yang berwenang dalam melakukan pencegahan dan pemberantasan Narkoba. Institusi pertama adalah Badan Narkotika Nasional dengan dasar hukum Undang-Undang No 35 Tahun 2009 tentang Narkotika. Institusi kedua yaitu Kepolisian Negara Republik Indonesia (Polri)

\footnotetext{
${ }^{11}$ Soerjono Soekanto \& Sri Mamudji, "Penelitian Hukum Normatif (Suatu Tinjauan Singkat)”, Rajawali Pers, Jakarta, 2001: 13.
} 
sebagaimana yang diatur dalam Pasal 13 Undang-Undang Nomor 2 Tahun 2002 tentang Kepolisian Negara Republik Indonesia. ${ }^{11}$

Salah satu unsur penegak hukum yang ada di Indonesia adalah Kepolisian Republik Indonesia (POLRI). Polri sebagai garda terdepan dalam melaksanakan pencegahan dan pemberantasan penyalahguna narkotika di negara ini. Agar dapat berjalan efektif, dalam menjalankan tugas dan fungsinya Polri perlu bersinergi dan didukung oleh masyarakat. Polri sendiri telah menempatkan penyalahguna narkotika sebagai kasus yang mendapatkan prioritas atau diutamakan, namun tugas utama Polri dalam mengungkap kasus penyalahguna narkotika juga tidak akan berjalan efektif jika tidak didukung dan adanya peran serta dari semua elemen masyarakat. Pasal 2 Undang-Undang Nomor 2 Tahun 2002 tentang Kepolisian Republik Indonesia, fungsi kepolisian adalah "salah satu fungsi pemerintahan Negara di bidang pemeliharaan keamanan dan ketertiban masyarakat, penegakan hukum, perlindungan, pengayoman, dan pelayanan kepada masyarakat." Polri tugas pokoknya "memelihara keamanan dan ketertiban masyarakat serta berusaha menjaga dan memelihara akan kondisi masyarakat agar terbebas dari rasa takut atau kekhawatiran, sehingga ada rasa kepastian dan jaminan dari segala kepentingan, serta terbebas dari adanya pelanggaran norma-norma hukum".

Kewenangan Direktorat Reserse Narkoba Polda Jateng dalam penanganan tindak pidana Narkoba secara garis besarmya dapat dibagi menjadi 2 yaitu :

1. Melalui jalur "penal" (hukum pidana) dan

Upaya pencegahan kejahatan lewat jalur "penal" lebih menitik beratkan pada sifat "represif" (penindasan, pemberantasan, penumpasan) sesudah kejahatan terjadi. Kewenangan Direktorat Reserse Narkoba Polda Jateng dalam penanganan tindak pidana Narkoba, dimulai dari "penyelidikan, penyidikan dan penangkapan tersangka". Direktorat Reserse Narkoba dalam melakukan kewenangan mengacu pada Undang-Undang No 2 Tahun 2002 tentang Kepolisian, Kitab Undang-Undang Hukum Acara Pidana (KUHAP) dan Undang-Undang Nomor 35 tahun 2009 tentang narkotika.

Penerapan pidana terhadap tindak pidana narkotika dikenakan UndangUndang Nomor 35 tahun 2009 tentang Narkotika dapat dikenakan baik itu bagi masyarakat umum maupun anggota Polri. Prosesnya yang membedakan antara masyarakat umum dan anggota Polri, karena apabila anggota yang melakukan tindak pidana maka akan ada sidang kode etik.

Jika oknum polisi terbukti melakukan tindak pidana narkotika tetap harus menjalani hukuman. Bagi oknum anggota Polri yang terbukti melakukan penyalahguna narkotika dijerat dengan Peraturan Kepala Kepolisaian RI, untuk selanjutnya diproses ke sidang profesi atau sidang disiplin dengan disertai ancamam

11 Heriansyah, "Upaya Kepolisian Negara Republik Indonesia (Polri)Dalam Penanggulangan Penyalahgunaan Narkoba Pada Siswa SMA Negeri Di Wilayah Hukum Polres Sumbawa”, Jurnal Ilmiah Pendidikan Indonesia 1 (1), 2019. 
pemberhentian tidak dengan hormat. Jika hakim memutuskan oknum angota Polri dijatuhi hukuman 5 tahun atau lebih maka oknum tersebut dipecat dari Polri.

Perbuatan penyalahguna narkotika oleh oknum anggota Polri akan menurunkan rasa percaya dan citra Polri di masyarakat. Polri yang seharusnya bertugas melakukan pencegahan dan pemberanasan penyalahgunaan Narkoba malah terlibat dalam peredaran ataupun penggunaan Narkoba. Untuk meminimalisir terjadinya penyalahguna Narkoba oleh oknum Polri maka perlu diberikan tindakan yang tegas bagi oknum Polri yang melanggar agar memberikan efek jera. ${ }^{11}$

Terhadap adanya oknum anggota Polri yang melakukan tindak pidana, seperti penyalahgunaan narkotika terdapat sanksi yang dijatuhkan baik sanksi pidana maupun sanksi dari instansi yang bersangkutan. Terbukti bersalah atau tidak, oknum tersebut tetap menjalani sidang kode etik yang diatur dalam Perkapolri No. 14 Tahun 2011 Tentang Kode Etik Profesi Kepolisian Negara Republik Indonesia.

2. Melalui jalur "non penal" (bukan di luar hukum pidana).

Upaya lewat jalur "non penal" lebih menitik beratkan pada sifat "preventif yaitu pencegahan; penangkalan dan pengendalian) sebelum kejahatan terjadi. Upaya pencegahan dan pemberantasan tindak pidana narkotika ini akan diawali dengan upaya preventif dan preemtif, yaitu berupa, pencegahan, penangkalan dan pengendalian sebelum tindak pidana tersebut terjadi melalui kebijakan non penal yang kemudian dilanjutkan dengan upaya "penal" atau dengan upaya represif (penindasan, pemberantasan dan penumpasan) sesudah tindak pidana narkotika itu terjadi. Narkotika merupakan zat atau obat yang berasal dari tanaman atau bukan tanaman, baik sintetis maupun semi sintetis, yang dapat menyebabkan penurunan atau perubahan kesadaran, hilangnya rasa, mengurangi sampai menghilangkan rasa nyeri. Karena manfaatnya tersebut, maka pasokan terhadap narkotika sangat diperhitungkan di bidang kesehatan dan pengembangan ilmu pengetahuan. Efek penurunan kesadaran, misalnya dapat membantu pasien imsonia untuk dapat beristirahat, efek, penghilang nyeri juga sangat membantu pasien pasca operasi. Oleh sebab itu, peredaran narkotika tidak dilarang di Indonesia, yang dilarang adalah penyalahgunaan dan peredaran gelap narkotika. Dalam menanggulangi kejahatan Narkoba di wilayah Jawa Tengah dan sekitarnya melakukan: upaya preemtif (penyuluhan). Tindakan penyuluhan ini merupakan upaya pencegahan dengan mengenalkan bahaya dan ancaman narkaba kepada para generasi muda. Penyuluhan dilaksanakan di setiap sekolah menengah dan perguruan tinggi baik negeri maupun swasta.

Pencegahan dan pemberantasan Narkoba tidak cukup hanya melalui jalur penal dan non penal. Mengingat penyalahguna Narkoba merupakan kejahatan yang

11 Aulia Tohari, Abdul Rokhim, "Tinjauan Hukum Bidang Pembinaan Dan Pengamanan Terhadap Anggota Polri Yang Melakukan Penyalahgunaan Narkoba Berdasarkan Peraturan Pemerintah Ri Nomor 2 Tahun 2003 Tentang Peraturan Disiplin Anggota Polri”, Jurnal Legalitas 4 (2), 2019, 54-71.doi : 10.31293/lg.v4i2.4498 
luar biasa maka perlu langkah dan upaya yang luar basa juga dari Polri. Diskresi kepolisian sering dilaksanakan dalam upaya yang luar biasa dari Polri dalam usahanya melakukan pencegahan dan pemberantasan Narkoba. Dengan melakukan diskresi diharapkan dapat dapat mengisi kekurangan atau kelemahan instrumen hukum tersebut. Pada pelaksanaannya diskresi juga dapat berdampak positif dan negatif. Dampak negatif dari diskresi dapat diminimalisasi dengan adanya penagwasan dari atasan langsung terkait pelaksanaan diskresi tersebut. ${ }^{11}$

\section{B. Kendala Dan Solusi Kewenangan Direktorat Reserse Narkoba Polda Jateng Dalam Penanganan Tindak Pidana Narkoba}

Pada dasarnya undang-undang narkotika menganut konsep "strict liability" mengandung unsur pertanggungjawaban mutlak. Artinya "setiap orang yang memenuhi unsur-unsur pidana pada undang-undang narkotika dapat dipertanggungjawabkan secara mutlak”. Sesuai tujuannya undang-undang narkotika sebagai yang tertuang dalam Pasal 4 UU Narkotika. Pada pasal tersebut dijelaskan tentan fungsi UU Narkotika sebagai penecegahan dan pemberantasan narkotika di Indonesia. Dengan melakukan pencegahan dan pemberantasan narkotika diharapkan akan dapat menyelamatkan generasi penerus dari ancaman bahaya narkotika. ${ }^{11}$

Hariyanto (2018) dalam penelitiannya menjelaskan langkah pencegahan dan pemberantasan terhadap penyalahgunaan dan peredaran gelap Narkoba yang dilakukan oleh Polri agar dapat dilaksanakan secara perlu secara komprehensif dan multidimensional. Dalam melakukan tindakan pencegahan dan pemberantasan Narkoba, Polri perlu melibatkan masyarakat. Dengan melibatkan peran serta dari masyarakat maka peredaran Narkoba akan semakin sempit. Pelibatan unsur masyarakat akan menghilangkan stigma bahwa urusan pencegahabn dan pemberantasan Narkoba merupakan murni urusan pemerintah. ${ }^{11}$

Penegakan hukum merupakan "suatu usaha untuk wujudkan ide-ide keadilan, kepastian hukum dan kemanfaatan sosial menjadi kenyataan. Jadi penegakan hukum hakikatnya adalah proses perwujudan ide-ide". Menurut Soerjono Soekanto, penegakan hukum adalah "kegiatan menyerasikan hubungan nilai-nilai yang terjabarkan didalam kaidah/pandangan nilai yang mantap dan mengejawantah dan sikap tindak sebagai rangkaian penjabaran nilai tahap akhir untuk menciptakan, memelihara dan mempertahankan kedamaian pergaulan hidup".

Hutagaol (2019) dalam penelitiannya menjelaskan tentang adanya kendala dalam penegakan hukum terhadap tindak pidana narkotika yang dilakukan oleh pihak PPNS BNN dan Kepolisian. Kendala pertama faktor komunikasi, belum

\footnotetext{
${ }^{11}$ Anak Agung Gde Mahardi Prana, I Made Minggu Widyantara, Luh Putu Suryani, "Diskresi Kepolisian dalam Pemberantasan Tindak Pidana Narkotika”, Jurnal Analogi Hukum, 1 (1), 2019, 1621.doi: https://doi.org/10.22225/ah.1.1.1453.16-21

${ }^{11}$ Deni Setya Bagus Yuherawan, Baiq Salimatul Rosdiana, "Ketidaktepatan Penjatuhan Pidana Penjara Terhadap Penyalahguna Narkotika”, Jurnal Ius Constituendum 5 (2), 2020, 177-195.doi : 10.26623/jic.v5i2.2207

${ }^{11}$ Bayu Puji Hariyanto, "Pencegahan Dan Pemberantasan Peredaran Narkoba", Jurnal Daulat Hukum 1 (1), 2018. doi: http://dx.doi.org/10.30659/jdh.v1i1
} 
terjalinnya komunikasi dan koordinasi diantara BNN dan Polri dalam pemberantasan Narkoba. Kendala selanjutnya adalah sistem perekrutan penyidik PPNS BNN yang kurang efektif, hal ini timbul karena proses rekruitmen yang dilakukan BNN dalam menambah sumber daya manusia relatif lama. Proses rekruitmen yang meliputi pendidikan dan pelatihan dirasa cukup lama sedangkan predaran Narkoba semakin meluas. Adanya aturan yang masih tumpeng tindih kewenangan antara BNN dan Polri juga menjadi kendala. Perbedaan kewenangan penyidik Polri dan PPNS BNN akan berpotensi menimbulkan permasalahan di lapangan. ${ }^{11}$

Penegakan hukum yang efektif adalah penegakan hukum yang dilaksanakan dengan memegan prinsip kebenaran dan keadilan . Tugas dari penegakan hukum tidak hanya dilakukan oleh penegak hukum pada umumnya tetapi juga menjadi tanggung jawab masyarakat. Sehingga akan tercipta lingkungan yang tertib, aman dan damai di masyarakat. Hal ini bukan berarti menghilangkan tugas dari pemerintah, dalam kaitannya dengan penegakan hukum publik tetap menjadi tanggung jawab pemerintah.

Dalam mengungkap kasus Narkoba Direktorat Reserse Narkoba Polda Jawa Tengah juga mengalami hambatan. Berikut akan diuraikan beberapa faktor yang mempengaruhi terhambatnya pengungkapan kasus penyalahgunaan Narkoba yaitu sistem jaringan yang terputus antara bandar, pengedar dan pengguna, personil yang kurang dan modus operandi yang bermacam-macam seperti barang narkotika ditanam dialamat tertentu dengan sistem pembayaran transfer sehingga mempersulit Kepolisian dalam mengungkap kejahatan tersebut.

\section{E. PENUTUP}

Kewenangan Direktorat Reserse Narkoba Polda Jateng dalam penanganan tindak pidana Narkoba secara garis besarmya dapat dibagi menjadi 2 yaitu lewat jalur "penal" (hukum pidana) dan jalur non penal. Dalam penerapan pidana terhadap tindak pidana narkotika dikenakan Undang-Undang Nomor 35 tahun 2009 tentang narkotika, baik itu bagi masyarakat umum maupun anggota Kepolisian. Prosesnya yang membedakan antara masyarakat umum dan anggota Kepolisian, karena apabila anggota yang melakukan tindak pidana maka akan ada sidang kode etik yang diatur tersendiri dengan aturan yang berlaku yaitu Perkapolri No. 14 Tahun 2011 Tentang Kode Etik Profesi Kepolisian Negara Republik Indonesia. Pelanggaran terhadap aturan disiplin dan kode etik akan diperiksa dan bila terbukti akan dijatuhi sanksi. Penjatuhan disiplin serta sanksi atas pelanggaran Kode Etik tidak menghapus tuntutan pidana terhadap anggota polisi yang bersangkutan seperti yang tercantum pada Pasal 12 ayat (1) PP No. 2 Tahun 2003 jo Pasal 28 ayat (2) Perkapolri No. 14 Tahun 2011. Oleh karena itu, oknum polisi yang menggunakan narkotika tetapi akan diproses hukum acara pidana walaupun telah menjalani sanksi disiplin dan sanksi pelanggaran

${ }^{11}$ Ramses Hutagaol, "Perbandingan Kedudukan Penyidik Tindak Pidana Narkotika Menurut UndangUndang Nomor 35 Tahun 2009 Tentang Narkotika Dan Kitab Undang-Undang Hukum Pidana", Jurnal Ilmiah Penegakan Hukum, 6 (2), 2019. doi: https://doi.org/10.31289/jiph.v6i2.2727 
kode etik. Jalur non penal yaitu dengan memberikan penyuluhan-penyuluhan tentang bahayanya narkotika kepada masyarakat maupun anggota kepolisian serta ancaman pidana bila mereka melakukan tindak pidana narkotika. Dalam menanggulangi kejahatan Narkoba di wilayah Jawa Tengah dan sekitarnya telah dilakukan oleh Direktorat Reserse Narkoba Polda Jateng berupa upaya penal dengan melakukan tindakan represif. Penindakan hukum yang tegas bagi para pelanggar penyalahguna narkotika. Penindakan hukum secara tegas juga tidak pandang bulu baik itu kepada masyarakat maupun kepada oknum anggota Polri. Upaya kedua adalah melalui jalur non penal salah satunya melalui upaya pre-emtif (penyuluhan). Tindakan penyuluhan ini merupakan upaya pencegahan dengan mengenalkan bahaya dan ancaman narkaba kepada para generasi muda. Penyuluhan dilaksanakan di setiap sekolah menengah dan perguruan tinggi baik negeri maupun swasta.

\section{DAFTAR PUSTAKA}

Harun M.Husen, "Kejahatan dan Penegakan Hukum Di Indonesia”, Rineka Cipta, Jakarta, 1990

Anak Agung Gde Mahardi Prana, I Made Minggu Widyantara, Luh Putu Suryani, "Diskresi Kepolisian dalam Pemberantasan Tindak Pidana Narkotika”, Jurnal Analogi Hukum, 1 (1), 2019. DOI: https://doi.org/10.22225/ah.1.1.1453.16-21

Aulia Tohari, Abdul Rokhim, "Tinjauan Hukum Bidang Pembinaan Dan Pengamanan Terhadap Anggota Polri Yang Melakukan Penyalahgunaan Narkoba Berdasarkan Peraturan Pemerintah Ri Nomor 2 Tahun 2003 Tentang Peraturan Disiplin Anggota Polri”, Jurnal Legalitas 4 (2), 2019.doi : 10.31293/lg.v4i2.4498

Bayu Puji Hariyanto, "Pencegahan Dan Pemberantasan Peredaran Narkoba”, Jurnal Daulat Hukum 1 (1), 2018. DOI: http://dx.doi.org/10.30659/jdh.v1i1

Deni Setya Bagus Yuherawan, Baiq Salimatul Rosdiana, "Ketidaktepatan Penjatuhan Pidana Penjara Terhadap Penyalahguna Narkotika", Jurnal Ius Constituendum 5 (2), 2020. doi : 10.26623/jic.v5i2.2207

Ferry Kurniawan Goenawi, "Batas Kewenangan Antara Penyidik Polri Dalam Penegakan Tindak Pidana Narkoba”, Badamai Law Journal 4 (2), 2019.

Hendar Firdaus, La Ode Husen,Abdul Agis, "Efektivitas Fungsi Institusi Kepolisian Dalam Pemberantasan Narkotika Di Kota Makassar", Jurnal Of Lex Generalis 1 (6), 2020. doi: https://doi.org/10.52103/jlg.v1i6.215

Heriansyah, "Upaya Kepolisian Negara Republik Indonesia (Polri)Dalam Penanggulangan Penyalahgunaan Narkoba Pada Siswa SMA Negeri Di Wilayah Hukum Polres Sumbawa”, Jurnal Ilmiah Pendidikan Indonesia 1 (1), 2019.

https://suduthukum.com/2018/01/teori-bekerjanya-hukum.html

Kholilur Rahman, "Problem Pengaturan Upaya Paksa Penangkapan Terhadap Pelaku Tindak Pidana Narkotika”, Jurnal Hukum Ius Quia Iustum 27 (3), 2020.doi : 10.20885/iustum.vol27.iss3.art3

Kunarto, "Polisi Harapan dan Kenyataan”, Klaten : Sahabat, 1997 
Kusno Adi, "Kebijakan Kriminal Dalam Penanggulangan Tindak Pidana Narkotika Oleh Anak”, UMM Press, Malang, 2009

Moh. Taufik Makaro, Suhasril dan Moh. Zakky, :Tindak Pidana Narkotika”, Ghalia Indonesia, 2003

O.C Kaligis \& Associates, Narkoba dan Peradilannya Di Indonesia, Cetakan ke-2 (PT. Alumni Bandung, 2007

Peraturan Kepolisian No 14 Tahun 2011 Tentang Kode etik Kepolisian

Peraturan Pemerintah No 2 Tahun 2003 Tentang Disiplin Anggota Kepolisian

Ramses Hutagaol, "Perbandingan Kedudukan Penyidik Tindak Pidana Narkotika Menurut Undang-Undang Nomor 35 Tahun 2009 Tentang Narkotika Dan Kitab Undang-Undang Hukum Pidana", Jurnal Ilmiah Penegakan Hukum, 6 (2) 2019. doi: https://doi.org/10.31289/jiph.v6i2.2727

Soerjono Soekanto \& Sri Mamudji, "Penelitian Hukum Normatif (Suatu Tinjauan Singkat)", Rajawali Pers, Jakarta,2001

Tri Wahono, Burham Pranawa, Joko Mardiyanto, “Peranan Polri Dalam Pencegahan Dan Pemberantasan Penyalahgunaan Peredaran Gelap Narkoba Di Wilayah Hukum Polres Boyolali(Studi Kasus Di Polres Boyolali)", Jurnal Bedah Hukum 3 (2), 2019.

Undang-Undang No. 35 Tahun 2009 Tentang Narkotika, 2009

Undang-Undang No 2 Tahun 2002 Tentang Kepolisian

Wenda Hartanto, "Penegakan Hukum Terhadap Kejahatan Narkotika dan Obat-Obat Terlarang Dalam Era Perdagangan Bebas Internasionla Yang Berdampak Pada Keamanan dan Kedaulatan Negara”, Jurnal Legislasi 14 (1), 2017. 